\title{
Rethinking Feminist Organizations
}

\author{
Patricia Yancey Martin
}

Gender and Society, Vol. 4, No. 2. (Jun., 1990), pp. 182-206.

Stable URL:

http://links.jstor.org/sici?sici=0891-2432\%28199006\%294\%3A2\%3C182\%3ARFO\%3E2.0.CO\%3B2-4

Gender and Society is currently published by Sage Publications, Inc..

Your use of the JSTOR archive indicates your acceptance of JSTOR's Terms and Conditions of Use, available at

http://www.jstor.org/about/terms.html. JSTOR's Terms and Conditions of Use provides, in part, that unless you have obtained prior permission, you may not download an entire issue of a journal or multiple copies of articles, and you may use content in the JSTOR archive only for your personal, non-commercial use.

Please contact the publisher regarding any further use of this work. Publisher contact information may be obtained at http://www.jstor.org/journals/sage.html.

Each copy of any part of a JSTOR transmission must contain the same copyright notice that appears on the screen or printed page of such transmission.

The JSTOR Archive is a trusted digital repository providing for long-term preservation and access to leading academic journals and scholarly literature from around the world. The Archive is supported by libraries, scholarly societies, publishers, and foundations. It is an initiative of JSTOR, a not-for-profit organization with a mission to help the scholarly community take advantage of advances in technology. For more information regarding JSTOR, please contact support@ jstor.org. 


\title{
RETHINKING FEMINIST ORGANIZATIONS
}

\author{
PATRICLA YANCEY MARTIN \\ Florida State University
}

This article analyzes feminist organizations as a species of social movement organization. It identifies 10 dimensions for comparing feminist and nonfeminist organizations or for deriving types of feminist organizations and analyzing them. The dimensions are feminist ideology, feminist values, feminist goals, feminist outcomes (for members and society), founding circumstances, structure, practice, members and membership, scope and scale, and external relations (legal-corporate status, autonomy, funding, and network linkages). I argue that many scholars judge feminist organizations against an ideal type that is largely unattainable and that excessive attention has been paid to the issue of bureaucracy versus collectivism to the neglect of other organizational qualities. The varieties of ideology, form, and strategy that feminist organizations embody should be analyzed in relation to outcomes for women, the women's movement, and society. As has recently begun to occur, feminist scholars are encouraged to claim the topic of feminist organizations for themselves.

\begin{abstract}
According to Katzenstein (1987, 5), the women's movements of the United States and Western Europe are a "political force that even in a single country has broad ideological variety and a range of organizational expressions" (my emphasis). What are feminist organizations and what is their range? Are they social movement organizations - vital components of the women's movement's history and future? Are they alternative, collectivist organizations that pursue autonomy and internal democracy above all? Are they institutional-

AUTHOR'S NOTE: An earlier version of this article was presented in the Sex and Gender Session at the American Sociological Association Annual Meeting in Atlanta, August 1988. I thank Beth Reed and Walda Fishman for encouraging me to write the article and my former students, Helga Zimmerer, Diane Byington, Maxine Thurston, and Sharon Maxwell, for their research on feminist and alternative social movement organizations. Special thanks go to Judith Lorber for help with clarifying the substance, and form, of the manuscript.
\end{abstract}

REPRINT REQUESTS: Patricia Yancey Martin, Department of Sociology, Florida State University, Tallahassee, Florida 32306-2011. 
ized social service agencies that have sold out to the state in exchange for financial resources? All of these claims are made in the literature, despite a dearth of empirical research and theorizing about their character, importance, role in the women's movement, or impact on individual women, the women's movement, and society.

Katzenstein (1987) believes that the women's movements' strength has been the emergence of local, and therefore less visible, feminist organizations. Feminist organizations with a national scope have played a vital role in the American women's movement's success (Costain and Costain 1987; Costin 1983; Ferree 1987; Freeman 1979; Gelb 1987). Many scholars believe that twentieth-century feminist organizations are key to understanding and perpetuating the development and spread of feminism as an instrument of personal and collective change (Ferree 1987; Katzenstein 1987; Klein 1987; Marieskind and Ehrenreich 1975; Mueller 1987). Others argue that feminist organizations can produce a better society in which bureaucratic organizations and the political economy on which they are constructed will wither away (Ferguson 1984, 1987; Gould 1979).

The aim of this article is to reformulate some of these issues and stimulate new research and theory. Feminist organizations in the modern Western women's movements have proved to be extraordinarily prolific, creative, variegated, and tenacious. No other social movement of the 1960 s, or later, has produced the rich variety of organizations that the women's movement has (Katzenstein 1987; Riger 1984; Taylor 1983). Many of these organizations have survived, furthermore, for more than two decades despite a purported waning of the movement. I argue that feminist organizations are a unique species of the genus of social movement organization (Cafferata 1982; McCarthy and Zald 1977; Riger 1984) and suggest that even the most institutionalized feminist organization helps to perpetuate the women's movement through, at the very least, exploiting the institutional environment of scarce resources (Freeman 1979; Mueller 1987; Staggenborg 1988).

In this article, I define feminist organizations and review contested issues, such as whether feminist organizations are social movement organizations. In doing so, I discuss their founding circumstances, the issue of internal structure, and demands for organizational purity. Second, I identify 10 dimensions that can be used to frame comparative research on feminist organizations. I argue that research should be inductive and dimensional rather than ideological and holistic in order to determine ways that feminist organizations are similar to and dissimilar from each other-and from nonfeminist organizations - and to understand better their structures, processes, and outcomes. 


\section{WHAT IS A FEMINIST ORGANIZATION?}

There is no consensus on the essential qualities of feminist organizations (cf. Gornick, Burt, and Pittman 1985; Riger 1984). Marx Ferree $(1987,188$ ) notes that liberal feminists in the American women's movement do not see hierarchy and bureaucracy as intrinsically antifeminist, whereas feminists of other ideological persuasions (radical, socialist, lesbian) often do (Baker 1982; Freeman 1979; Gelb 1987; Pittman, Burt, and Gornick 1984; Staggenborg 1989). Scholars of collectivist organizations tend, in contrast, to agree on their essential qualities: how authority, or control, is organized and the goal of participatory democracy (Blum 1982; Hacker and Elcorobairutia 1987; Rothschild-Whitt 1979a, 1979b; Rothschild and Whitt 1986; Zimmerer 1982). Democracy (minimal hierarchy, broad participation) is highly valued in most feminist organizations (Harvey 1985; Schechter 1982; Thurston 1987); and recent research by Knoke (1989) shows that women's political organizations are more democratic in a variety of ways than are organizations of several other types (e.g., professional, recreational). Few scholars claim that an organization must have a collectivist structure to qualify as feminist, although activists committed to collectivist organizations have tended to make such claims (see Ahrens 1980; Ferguson 1987; Pahl 1985; Peterson and Bond 1985; Riger 1984; Schlesinger and Bart 1982; Tierney 1982).

\section{Defining Feminist Organization}

To clarify the nature of feminist organizations, the meanings of feminism and organization must be addressed. Feminism is a broad, multifaceted political orientation rather than a single ideology (Ferree 1987; Jaggar 1983; Jaggar and Rothenburg 1984). I agree with Katzenstein (1987) that feminism is (minimally) the recognition that women, compared to men, are an oppressed group and that women's problems are a result of discrimination. Women's status is shaped by processes of structural inequality, not individual actions or circumstances. Feminism is transformational because it involves a vision of society that does not exist and sees social, political, and economic change as necessary for that vision to be realized (Mueller 1987; Taylor 1983). Feminism's political perspective is pro-woman and favors changes to improve women's collective status, living conditions, opportunities, power, and self-esteem. A feminist organization, therefore, is pro-woman, political, and socially transformational (Freeman 1979). This definition allows feminist programs of mainstream organizations to be counted as feminist, for 
example, rape crisis centers associated with general hospitals or mental health agencies.

What is an organization? In answering this question, the difference between an organization and a group must be addressed because many feminists (and other social activists) cluster in groups rather than in formal organizations (see Staggenborg [1988] for a discussion of the lack of precision in social movement research on this issue). One claim is that organizations have a formal, often legal-corporate, status and structure and are relatively permanent, whereas groups have less structure and are more informal and ephemeral (Martin and O'Connor 1989). Reality is rarely so neat. Many organizations have only voluntary members, and many groups have elaborate internal structures and long and stable life spans. For my purposes, I define organization as any relatively enduring (exists for more than a few sessions or meetings) group of people that is structured to pursue goals that are collectively identified. Structure is defined as an intentional or emergent plan of organization, strategy, and goals that may or may not be reproduced in official tables of organization, constitutions, and job descriptions. This definition allows consciousness-raising groups, so prevalent in the early stages of the modern women's movement (Ferree and Hess 1985; Freeman 1979), to be viewed as feminist organizations.

Summing up these points and using literature and research that $I$, colleagues, and graduate students have conducted (Blum 1982; Byington et al. forthcoming; Martin and DiNitto 1987; Martin et al. 1984; Maxwell 1987; Thurston 1987; Zimmerer 1982), I suggest that an organization is feminist if it meets any one of the following criteria: (a) has feminist ideology; (b) has feminist guiding values; (c) has feminist goals; (d) produces feminist outcomes; (e) was founded during the women's movement as part of the women's movement (including one or more of its submovements, e.g., the feminist self-help health movement, the violence against women movement, see Largen 1981; Pride 1981).

Feminist organizations are profit making as well as not-for-profit, hierarchical as well as collectivist, national as well as local, illegal as well as legal, dependent as well as autonomous. Feminist organizations include the $\mathrm{Na}$ tional Organization for Women (NOW), with its 250,000 dues-paying members and full-time paid staff, the underground Jane collective that provided illegal abortions to women through voluntary labor prior to the 1973 Supreme Court decision, rape crisis centers that rely on volunteers or paid staff to help rape survivors and educate about rape, consciousness-raising groups, and for-profit recording companies that market feminist records (cf. Ferree and Hess 1985). Organizations that disavow feminist ideology may have other 
feminist characteristics. These are the organization's founding circumstances or its espousal of feminist values, goals, or outcomes - such as societal change to improve women's status, the development of women's personal skills or relationships or self-esteem as a process of micropolitical change, or transforming women's political consciousness (Ahrens 1980; Amir and Amir 1979; Baker 1982; Ferguson 1984, 1987; Ferree 1987; Gelb 1987; Gornick, Burt, and Pittman 1985; King and Webb 1981; Lorber 1985; Loseke and Cahill 1984; Maxwell 1987; Riger 1984; Rodriguez 1988; Schechter 1982; Searles and Berger 1987; Staggenborg 1988, 1989; Tierney 1982; Thurston 1987).

\section{SOME CONTESTED ISSUES}

\section{Are Feminist Organizations Social Movement Organizations?}

I would argue that feminist organizations are a species of social movement organization associated with the twentieth-century women's movements of the United States and Western Europe (Drachman 1984; Freedman 1979). Some feminist organizations were founded coterminously with other social movements, especially the counterinstitutional movements of the 1960s that promulgated alternative institutions, collectivist and participatory democratic organizations, self-help groups, and health care reform (Rothschild 1987; Staggenborg 1989; Starr 1979; Taylor 1983). Since an early form of feminist organization was collectivist, feminism and collectivism are confounded in much of the literature (see Freeman 1979). Feminist organizations that combine the qualities of social movement organizations and mainstream, professional service organizations are criticized as having been coopted (Ahrens 1980; Andler and Sullivan 1980; Ferraro 1981, 1983; Johnson 1981; Schechter 1982; Tierney 1982). In actuality, few feminist organizations reflect a pure or ideal type, and scholars should use caution in labeling mixed types as coopted, institutionalized, or no longer part of the women's movement.

Resource mobilization theory (McCarthy and Zald 1977, 1217-18) defines a social movement as "a set of opinions and beliefs in a population which represents preferences for changing some elements of the social structure and/or reward distribution of a society" and a social movement organization as "a complex, or formal, organization which identifies its goals with the preferences of a social movement or a countermovement and attempts to implement these goals" (p. 1218). From a resource mobilization perspective, feminist goals, and employment of strategies and tactics to 
pursue feminist goals, are required for an organization to be viewed as a feminist movement organization. I suggest broadening the criteria to include feminist ideology, values, outcomes, and founding circumstances as additional definitional grounds (for a similar view, see Ferree and Miller 1985). This will allow those who study feminist organizations to encompass their full range.

\section{Founding Circumstances}

Cafferata (1982) claims that the circumstances of organizational founding or birth determine if an organization belongs to a particular organizational species. In the present case, an organization is counted as belonging to the feminist organization species if it was founded as part of the women's movement. The date on which it was founded and the aspect of the women's movement with which it was associated at founding can be used to determine whether an organization is to be considered feminist.

In the United States, the women's movement of the last two decades developed along with, and was influenced by, the civil rights and radical or counterinstitutional movements (youth, free speech, anti-Vietnam War, alternative democratic institutions, antinuclear, environmental protection, gay rights, consumer rights, self-help, and so on). Early in the recent movement (termed by Ferree and Hess [1985] the New Women's Movement), some feminists (called the older branch by Freeman [1979]) founded large, national, bureaucratic, externally oriented feminist organizations, whereas others (the younger branch) founded small, localized, collectivist, internally oriented feminist organizations (Freeman 1975, 1979).

Younger-branch feminists rejected the chauvinism of men in the leftist, alternative institution movements, but they endorsed the goals of internal democracy, avoidance of elitism and hierarchy, and collectivist authority and control that these movements hailed. Older-branch feminists were influenced primarily by the earlier (nineteenth- and early twentieth-century) women's movement and saw nothing wrong in founding adversarial organizations that were hierarchical (Starr 1979). While the founders of the more hierarchical organizations valued organizational democracy, they did not make it the primary goal (Costain and Costain 1987; Freeman 1979). Freeman (1979), along with others, labels the two forms of early feminist organization in the United States as associational (e.g., NOW) and communal (e.g., feminist collectives).

Feminist organizations that were founded later tended to fit neither of these molds (Gornick, Burt, and Pittman 1985; Riger 1984). These included women's service organizations (feminist women's health clinics, rape cri- 
sis centers, battered women's shelters, birthing centers, displaced homemaker programs); women's consciousness-raising and self-defense groups; witches' covens; women's cooperatives for distribution of food, books, records, or clothing; women's for-profit establishments selling feministoriented travel, entertainment, retail goods, and so on. Many of these organizations, such as rape crisis centers and the anti-rape movement, reflected particular aspects of women's movement development. Since these organizations were founded at a later time, they reflect later developments in the movement; and they had more particularized ideologies, values, goals, and outcomes than the earlier women's movement organizations did.

\section{Institutionalization}

Feminist organizations, like most organizations, change with time. Social movement organizations that develop stable ties with government are said to become institutionalized and to forfeit their social movement status (Lowi 1971; Piven and Cloward 1977), although others disagree with this claim (McCarthy and Zald 1973, 1977; Staggenborg 1988; Zald and Ash 1966). Freeman (1979) says that feminist organizations exploit their institutional environments for valued resources as much as, if not more than, the environment coopts them; and a body of research on feminist organizations agrees. Simon (1982) found that government funding for a rape crisis center provided stability and security and did not undermine commitment to feminist goals. Matthews (1989) found that government funding encouraged a movement goal, racial integration. Gornick, Burt, and Pittman (1985) found similar results in their research on a national U.S. sample of rape crisis centers (also see, Martin et al. [1984], Maxwell [1987] on rape crisis centers; Kleiber and Light [1978], Ruzek [1978], Thurston [1987], Zimmerer [1982] on women's health centers). Negative effects of institutionalization were found by Ahrens (1980), Andler and Sullivan (1980), Johnson (1981), and Rothschild-Whitt (1979b).

\section{Internal Structure}

The literature on feminist organizations has focused heavily on internal structure, to the neglect of other qualities (Baker 1982; Freeman 1979). Feminist organizations assume many structural forms, and a common internal structure (e.g., collectivist) does not preclude other differences. I suggest, in fact, that a particular internal structure is not a defining characteristic of feminist organization. 


\section{Organizational Purity}

An assumption is often made in the literature that to be truly feminist, an organization must live up to an ideal type (cf. Baker 1982; Ferguson 1984; Ferree 1987). Inconsistencies of goal and practice; the decoupling of structure and activity; conflicting values, goals, practices, and outcomes circumstances that characterize practically all ongoing organizations - are depicted as fatal or disqualifying flaws. Understanding the variety of forms and practices of feminist organizations requires a comparative perspective that leaves open questions of legitimacy.

\section{TEN DIMENSIONS OF FEMINIST ORGANIZATIONS}

Ten dimensions along which feminist organizations can differ are outlined in Table 1. Any of the first five dimensions can, in my opinion, qualify an organization as feminist. Some feminist organizations will score as feminist on all of the first five dimensions, but this does not mean that organizations that fail to do so are necessarily less feminist. The last five dimensions are not unique to feminist organizations but are widely discussed in the feminist literature. They are included to indicate additional dimensions on which feminist organizations can vary and still qualify as feminist. They can also serve as a guide to comparative research to identify and analyze the rich variety of forms and practices that feminist organizations embody.

Ideally, any organization can be analyzed using these dimensions, but they are particularly useful for distinguishing feminist from nonfeminist organizations. An organization that is not feminist on ideology may qualify as feminist on goals, values, outcomes, or founding circumstances. For example, working-class women's organizations, such as Nine to Five or the Coalition of Labor Union Women, deny that they are feminist; but they clearly have, and pursue, feminist goals (Klein 1984, 1987). Collectivist organizations that eschew hierarchy and value participatory democracy and have many features in common with feminist collectives may not be defined as feminist if they lack any uniquely feminist characteristics such as feminist values, goals, or outcomes (see Ferguson [1987] and Rothschild [1987] for differing views on this point).

\section{Feminist Ideology}

Ideology concerns generalized beliefs that make sense of and direct attention to particular aspects of social reality and that include a conception 
TABLE 1: Ten Dimensions of Feminist Organizations

I. FEMINIST IDEOLOGY: Does the organization officially endorse feminist beliefs associated with the women's movement? If yes, is it liberal feminist, radical, socialist, Marxist, lesbian, other? Does the organization unofficially endorse feminist beliefs? Are women's subjective consciousness or economic and material conditions emphasized (or both)? With which moral, ethical, personal, and political issues is the organization most concerned?

II. FEMINIST VALUES: Does the organization emphasize the importance of mutual caring, support, cooperation, interpersonal relationships, personal growth, development and empowerment? Is work conceptualized as a social, rather than technical, relationship? Is technology viewed as a tool accessible to all, not merely to experts? Are internal democracy, fairness, and self-help positively valued?

III. FEMINIST GOALS: Does the organization have an internal action agenda that helps members see women as an oppressed group and encourages women to change (politically, personally)? Does the organization have an external action agenda aimed at improving women's status or opportunities in society? Does it take steps to pursue these goals? Is political (feminist) analysis of women's oppression a part of the action agenda?

IV. FEMINIST OUTCOMES: Are members transformed by participation in the organization? Does participation change them subjectively or materially (e.g., self-esteem or empowerment, earnings, status, their conception of women's oppression as a political issue requiring social change)? Is society (local or national; staff in other agencies; local, state, federal laws; public opinion) transformed by organizational activities, to women's benefit?

V. FOUNDING CIRCUMSTANCES: What date was the organization founded? In association with what stage or aspect of the women's movement (e.g., the anti-rape movement)? Was founding associated with other social movements? If so, which?

VI. STRUCTURE: What are the organization's normative internal arrangements? In what ways is the organization bureaucratic, collectivist? How is work divided up and integrated? How are decisions supposed to be made? How are conflicts supposed to be resolved?

VII. PRACTICES: What activities do members (or others) perform in pursuit of internal and external goals? Are practices consistent with feminist ideology, values, and normative structural arrangements? How do members justify their practices? What are the latent functions of practices? What are the semiotics of practice?

VIII. MEMBERS AND MEMBERSHIP: What are the requirements for membership? What are the characteristics of members (e.g., gender, political views, age, race and ethnicity, social class)? What are the categories of members? How are members recruited, affiliated, and terminated? What is a typical member's career? What status distinctions are made and why? 
TABLE 1 Continued

IX. SCOPE AND SCALE: Is the organization local, national (or other) in scope? Is its orientation internal (toward members) or external (toward societal change). How many different types of activities does it engage in? How many members does it have, how many women does it serve or deal with annually? What size budget does it have?

$X$. EXTERNAL RELATIONS: How is the environment conceptualized-as hostile, neutral, friendly? How is the organization linked to its social, cultural, political, and economic environments? (a) What is its legal-corporate status vis-à-vis the state? (b) How autonomous is it? (c) Where does it obtain funding (financial resources)? (d) To which external groups and organizations is it linked? What form do linkages take? Around what issues are linkages made? How are linkages (and nonlinkages) conceptualized and enacted? How many links are there? How intense are they?

of the world as it should be (McCarthy and Zald 1977; Taylor 1983). Ideology is broader and more nebulous than guiding values or goals and includes a rationale for the organization's existence, mission, and range of activities and concerns. Ideology is present in every organizational context, whether it is acknowledged or not (Turner 1986).

Feminist ideology sees women as a "sex-class," acknowledges that women are oppressed and disadvantaged as a group, sees this as rooted in social arrangements, and articulates beliefs that its correction, or elimination, requires social, political, and economic change (Eisenstein 1981; Katzenstein 1987; Pahl 1985; Taylor 1983). Much of the literature depicts feminist organizations as explicitly feminist in ideology (see Ahrens 1980; Baker 1982; Ferguson 1984, 1987; Freeman 1972-73), although numerous studies report that leaders of some organizations that were spawned by the feminist movement, that endorse feminist values, and that pursue feminist goals deny, when asked explicitly, that their organizations are feminist (see Gornick, Burt, and Pittman 1985; Pittman, Burt, and Gornick 1984; Harvey 1985).

If an organization officially or unofficially endorses a feminist ideology, the ideology can be classified according to type: liberal, radical, socialist, Marxist, lesbian, or other (Ferree 1987; Jaggar 1983; Jaggar and Rothenburg 1984; Taylor 1983). Most mass-membership and national feminist organizations in the United States are officially liberal feminist, but Taylor (1983) argues that their action agendas have become increasingly radical since the late 1970s (also see Klein 1987). Taylor views modern feminist ideology as very comprehensive and as strongly allied with other social movements such as antipoverty, antinuclear, and so on. In her view, feminist ideology demands that "American society be changed according to feminist principles so that it is a just and fair society for all people regardless of sex, race, class, sexual 
politics, or any other social characteristic" (Taylor 1983, 438). Viewed in this light, feminist ideology is extraordinarily broad.

Ideological claims and disclaimers can tell us only what organizational leaders (or official documents) assert to be true or are willing to admit. Examination of other dimensions is necessary to assess whether an organization is feminist in action as well as belief (Marieskind and Ehrenreich 1975) and to what extent the organization implements its professed ideology. A focus on ideology can, however, help determine the extent to which open espousal is necessary for effective political action and whether serviceoriented organizations tend to mute ideology to serve a wider population or to accommodate resource providers. In any event, ideological stance can be analyzed in relation to other dimensions, including organizational outcomes.

\section{Feminist Values}

Values are normative preferences that are invoked as guides to goal formation, action, planning, policy making, and so on. Values are general, with no particular behavior attached to them, whereas goals are more specific and require action for their accomplishment. Taylor $(1983,445)$ contrasts feminist values with masculinist values as "egalitarianism rather than hierarchy, cooperation rather than competition, nurturance rather than rugged individualism, peace rather than conflict." Feminist values have been described as stemming from political analysis of women's lived experiences (Gornick, Burt, and Pittman 1985; Rodriguez 1988; Smith 1987). They focus on the primacy of interpersonal relationships; empowerment and personal development of members; building of self-esteem; the promotion of enhanced knowledge, skills, and political awareness; personal autonomy; and the politics of gender (Ferguson 1984, 1987; Ferree 1987; Freeman 1975; Gelb 1987; Leidner forthcoming; Rothschild 1987). Feminist values conceptualize service as a social relationship rather than a technological transfer of expertise, and the sharing of technology and information through a self-help rather than expert-naive recipient format (Marieskind and Ehrenreich 1975; Lorber 1985; Thurston 1987). Many treatises claim that internal democracy is a central value of feminist organizations, including those that are bureaucratically structured (Freeman 1979; Ferree 1987; Staggenborg 1988, 1989). Feminist values assert that society must change to be fairer, less violent, and more supportive to women (Costain and Costain 1987).

A feminist organization's values provide a clue to self-image. It may see itself as a model or prototype for emulation as an alternative organization or as an adversary with an aim of changing society through open confrontation (Starr 1979). This depends, in part, on its leaders' and members' sense of their 
centrality or marginality in a community (and nation-state) and on their vision of the organization's purpose and mission.

\section{Feminist Goals}

Goals are action agendas that an organization claims it wishes to achieve and that it actually pursues (Hall 1986). (Stated goals are attested to and operative goals are actively pursued.) Most organizations have multiple and conflicting goals and constituencies (Cameron 1986; Martin 1987b), and feminist organizations are no exception. Consensus on goals, on which are most important, and on how they should be pursued is problematic in feminist organizations as elsewhere (Baker 1982; Drachman 1984; Ferraro 1983). Goals are nevertheless useful for studying and comparing feminist organizations.

Feminist organizations have three major types of goals: (a) to change their women members by improving their self-esteem, political awareness, skills, and knowledge (Gould 1979; Ferguson 1987; Ferree 1987; Gelb 1987; Peterson and Bond 1985; Riger 1984; Searles and Berger 1987); (b) to serve women generally through providing education or services such as political education, personal counseling, health care, shelter from batterers (Ahrens 1980; Amir and Amir 1979; Ferraro 1981; Gornick, Burt, and Pittman 1985; King and Webb 1981; Martin et al. 1984; Morrison 1982; Pahl 1985; Simon 1982; Tierney 1982); and (c) to change society so that women's status, treatment, opportunities, and condition in life are improved (Costain and Costain 1987; Riger 1984; Rose 1977).

Some feminist organizations concentrate on helping members only - for example, many autonomous feminist collectives (Ferree 1987; Gelb 1987) whereas others focus on public goods such as changing discriminatory laws that affect women, electing more women to political office, lobbying for universal day care - for example, the National Organization for Women (Costain and Costain 1987; Freeman 1979; Klein 1987; Knoke 1989). Thus feminist organizations can be compared on whether their operative goals are primarily internal (that is, directed toward their members) or external (directed toward society) or both (see Table 1). Stated somewhat differently, goals can be analyzed in terms of their emphasis on personal versus societal transformation.

\section{Feminist Outcomes}

Feminist outcomes are the consequences for members, for all women, and for local and national societies of feminist organization activities. Feminist 
organizations are reported to have improved members' self-esteem, sense of power and autonomy, skills and knowledge, political awareness, and consciousness of women's oppression (Baker 1982; Ferree 1987; Gelb 1987; Pittman, Burt, and Gornick 1984; Searles and Berger 1987; Simon 1982) and to have transformed society through their exemplary and adversarial activities (Gould 1979; Starr 1979; Staggenborg 1988). There is general agreement that the American women's movement has profoundly affected expectations and perceptions of possibilities for women (Gelb 1987; Taylor 1983), but whether this was accomplished by feminist organizations is disputed. For example, Mueller (1987) claims that the dramatic increase in women candidates for elected political office in the United States is a result of a changed collective consciousness, not of the actions of feminist organizations. Staggenborg (1988), on the other hand, credits feminist organizations with having exercised "a progressive influence" on the entire U.S. political system (p. 604). Although an organization's impact on members, on women in the community, and on the community or society in general may be difficult to ascertain, we need analyses of outcomes in relation to other aspects of feminist organizations.

\section{Founding Circumstances}

Founding circumstances refers to the relationship of an organization's founding date to the women's movement (or submovements). If an organization was founded during the women's movement, in association with the movement, this is prima facie evidence that it is feminist (Cafferata 1982). (This assumes that beginning and ending dates of social movements can be determined.) Founding circumstances affect not only an organization's original form but its character and practices throughout its life span (Smith and Marcus 1984; Stinchcombe 1965). Feminist organizations founded in the early stages of the women's movement are, as suggested earlier, different from those founded later. These differences very likely reflect changes in the movement itself. Comparative analyses of feminist organizations founded at different time periods can give clues to feminist movement progression and change and insights into the interdependencies and dynamics of movement and social movement organizations (see Jenkins and Eckert 1986).

Founding circumstances relative to other social movements may be important also, since feminist organizations founded in association with other movements frequently experience severe conflicts. The failed feminist organization that Staggenborg (1989) studied was founded in association with other movements besides the feminist movement, saddling it with multiple values, goals, and members that it could not accommodate. 


\section{Structure}

Structure, an organization's normative internal arrangements, concerns the manner in which control or authority is organized and power is distributed, the way work is divided up and integrated, and the arrangements for decision making and conflict resolution. Structure refers to intended arrangements, whereas practices (Dimension VII) concern the way things are actually done.

The most frequently discussed structural issue in the feminist organizations literature is collectivist versus bureaucratic organization, or participatorydemocratic versus hierarchical authority and control (e.g., Baker 1982; Ferguson 1984; Freeman 1972-73; Gelb 1987; Gould 1979; Searles and Berger 1987; Thurston 1987). Early-movement feminists claim they created a new organizational type that organized authority collectively and assured democracy through a flat rather than hierarchical structure and through consensus decision making (Baker 1982; Freeman 1975; Largen 1981; Pittman, Burt, and Gornick 1984; Schlesinger and Bart 1981). Descriptions of these feminist organizations are very similar to alternative, grass-roots collectives (Rothschild-Whitt 1979a, 1979b; Rothschild and Whitt 1986). As noted earlier, some young feminists (Freeman 1979) discovered or invented collectivist organizations at the time they founded feminist organizations. Although feminist collectives may have had a distinctive feminist ideology, values, and goals, they shared a collectivist organizational structure with other alternative organizations that were spawned in the counterinstitutional, grass-roots democracy movements of the 1960s (Starr 1979).

As an ideal type, feminist organizations are depicted as having collectivist internal structures, although relatively few do so (Ahrens 1980; Harvey 1985; Martin et al. 1984; Maxwell 1987; Schechter 1982; Searles and Berger 1987; Tierney 1982). The structures of many feminist organizations are impure mixtures of bureaucracy and democracy rather than a single type (Gomick, Burt, and Pittman 1985; Staggenborg 1988; Thurston 1987). Cafferata (1982) argues that bureaucracy and democracy are compatible rather than incompatible processes, and some feminist organizations find that bureaucracy can have positive effects. Bureaucratic structures can facilitate goal accomplishment without exploiting members (Knoke 1989; Leidner forthcoming) and, indeed, can help assure fairness and effectiveness (Staggenborg 1988, 1989). Freeman (1973) notes that so-called structureless organizations are destructive, because unofficial leaders exercise unchecked influence over organizational decisions and processes (also see Baker 1982). Early feminists equated power with exploitation and domination, but power has recently come to be seen as an aspect of organizational structure that can be used positively as 
well as negatively - for people as well as against them (Freeman 1979). How power is actually used, and for what purposes, may be more important than its hierarchical or collectivist arrangement. The question of structure and intentional and unintentional outcomes is a particularly fruitful area for research on feminist organizations (see Leidner forthcoming; Martin 1987a; Staggenborg 1988, 1989).

\section{Practices}

Practices are the strategies and tactics that feminist organizations employ, both internally and externally. In contrast to normative prescriptions of how things should be done (i.e., structure), practices concern what actually occurs. Practices include the where and how of members' energy and time: what do they do, how often, in what manner? To whom and for what purposes are resources expended (i.e., money, time, energy, and attention)? How does the organization treat and recruit members, impart services, interact with outsiders? One issue here is whether feminist organizations employ a uniquely feminist praxis and, if so, the form it takes and with whom it is employed.

Marieskind and Ehrenreich (1975) say that study of doing is necessary to understand feminist organizations, and numerous scholars claim that feminist organizations do things in unique ways (Rodriguez 1988; Schlesinger and Bart 1981). For example, services are delivered in a way that empowers recipients within a social relations context that communicates caring and support. How services are delivered is emphasized as much as the services themselves. Is this a universal practice among feminist organizations? Analysis of feminist organization practices should include ethnomethodological studies of the gaps between prescription and practice and reasons for the gaps (e.g., Garfinkel's [1967] good practical reasons for bad clinical records). They should also explore the extent to which practices reflect feminist values such as nurturance, support, cooperation, and empowerment.

Strategies that feminist organizations employ relative to the world beyond their boundaries also require study (Ferree 1987). Is the environment a target for action? If so, what tactics are used to influence it? American feminist organizations are said to be pragmatic and eclectic in their use of political strategies to influence the environment, whereas West German and British feminist organizations interact with the environment minimally from fear of cooptation (Ferree 1987; Gelb 1987).

Many American feminist organizations negotiate with other organizations (including government), write proposals and compete for funding, try to change laws, and lobby, network, and form coalitions with other organizations on women's behalf (Gornick, Burt, and Pittman 1985; Harvey 1985; 
Martin et al. 1984; Maxwell 1987; Morrison 1982; Schechter 1982; Thurston 1987). Are the strategies they employ like those of other social movement organizations, or do feminist ideology, values, and goals make them unique? When a feminist organization tries to influence the public through demonstrating, speech giving, and advertisements on television and radio, is persuasion or protest emphasized (Costain and Costain 1987); and, in either case, what signals and words are used? The semiotics of practice in feminist organizations is an area that is ripe for research. We need analysis of the language that feminist organizations use to persuade or protest externally and to signal their values, ideology, and goals to both members and nonmembers. Which practices are most effective and why?

\section{Members and Membership}

Membership concerns who is viewed as appropriate to belong; the rules and regulations of belonging; and how members are recruited, incorporated, socialized, and terminated or how they voluntarily affiliate and leave. What qualities do members have? Must they hold particular ideological or political beliefs, as is the case in many feminist collectives (Ferree 1987; Gelb 1987), or is ideological diversity tolerated (as in the National Women's Studies Association; Leidner 1989)? What membership categories exist and how are they defined? Typical categories in feminist service organizations in the United States are paid staff, volunteers, clients, and board members (Thurston 1987). What is their relationship to each other? Do relationships among them differ for differently structured feminist organizations (see Rodriguez 1988)? How are members affiliated with the organization: do they pay dues, attend a minimum number of meetings, help with organizational tasks, receive wages or a salary, show up on the doorstep? What are typical careers of active members, marginal members, inner-circle members?

The where, how, and reasons for feminist organization boundaries that are drawn between members and others need to be studied. Marx Ferree (1987) notes that battered women's shelters in West Germany (with a radical feminist ideology) accept any woman who comes there, have no limits on length of stay, and make minimal distinctions among residents, volunteers, and paid staff (if there are any). Gelb (1987) reports that many feminist organizations in the United Kingdom are similar, but Rodriguez's (1988) study of a Hawaiian battered women's shelter found that conflicts over rights, privileges, and duties persist.

Some feminist organizations do not accept men as members (Baker 1982; Ferguson 1987; Ferree 1987; Freedman 1979; Gelb 1987; Gould 1979), whereas mass membership organizations, such as NOW, and funded move- 
ment organizations, such as Planned Parenthood and the National Abortion Rights Action League, accept them gladly. Few men hold office or staff positions in these organizations, however; and the vast majority of members and donors are women. Many feminist service organizations have men on policy-making or professional advisory boards (Gornick, Burt, and Pittman, 1985; Harvey 1985), but they are typically given low-visibility, if frequently powerful, roles (such as treasurer). Men may be used for instrumental purposes, such as physicians who perform abortions in feminist women's health centers. Their role is typically limited, however, to the abortion procedure (Kleiber and Light 1978; Thurston 1987; Zimmerer 1982). These men are not counted as organizational members, are not allowed to take part in organizational decisions, and hold no positions of authority. A question that research on feminist organizations might address is why men rather than women physicians are used to do the "dirty work" of abortion clinics (see Thurston 1987; Zimmerer 1982). If women physicians did the work, would they be viewed and treated as members? Analysis of the manifest and latent power associated with gender in feminist organizations that incorporate men in any capacity would be useful. This could advance understanding of the ways gender status infiltrates and is re-created through organizational status in both intentional and unintentional ways (see Acker 1990).

\section{Scope and Scale}

Scope refers to whether a feminist organization is local versus national. Scale refers to membership numbers, number and range of activities, number of clients served and services provided, and size of the annual budget. Both scope and scale are reported to affect the character and success of feminist organizations.

Ideal-type depictions assert that feminist organizations are local in scope and small in scale (Ferguson 1984, 1987). Katzenstein (1987, 5) attributes the women's movement's success to the development of localized feminist organizations that are barely visible to outsiders, and many feminist organizations in the United States are local - as frustrated efforts to develop censuses of them show (Delacoste and Newman 1981; Largen 1981). Marieskind and Ehrenreich (1975) report that early feminist women's health centers in the United States were "extremely local," and recent research confirms that this remains the case (Thurston 1987). Marx Ferree (1987) and Gelb (1987) describe feminist collectives in West Germany and Britain as localized organizations that eschew links with other organizations, local or otherwise. A local scope and orientation may make feminist organizations effective for 
women within a geographic area, but these same attributes isolate feminists from each other, segment the women's movement, and limit their impact on society (Gelb 1987).

In the United States, more than in Western Europe, feminist organizations with a national scope have flourished. These include NOW, with a membership of over 250,000 (easily the largest feminist organization in existence, ever), the National Women's Political Caucus, the Women's Equity Action League (WEAL), the National Abortion Rights Action League (NARAL), Planned Parenthood, and the National Women's Studies Association (Costain and Costain 1987; Gelb 1987; Leidner 1989). Large, traditional women's organizations that do not self-identify as feminist but whose action agendas are partially feminist include the League of Women Voters, the Coalition of Labor Union Women, and the National Federation of Business and Professional Women (Klein 1987).

Many discussions of feminist organizations suggest that only small organizations can be truly feminist (Ferguson 1984; Kleiber and Light 1978). Face-to-face, interpersonal exchange is more feasible in organizations with fewer members (Ferguson 1984; Mansbridge 1980, 1982), but the ability to sustain a long-term campaign over legal or political issues is easier for large organizations (Costain and Costain 1987; Gelb 1987; Mueller 1987). The significance of scale to impact should be studied to ascertain the consequences to feminist organizations of variable size (see Rothschild-Whitt 1979b).

\section{External Relations}

External relations concern the nature, intensity, and content of an organization's ties to its environment or to the individuals, groups, and organizations (including the state) beyond its boundary. I discuss external relations in four categories: legal-corporate status, autonomy, funding, and network linkages. Although not entirely mutually exclusive, each focuses on a different aspect of external relations.

A. Legal-corporate status refers to an organization's relationship to the state. Fears of cooptation cause some feminist organizations to eschew relations with the state (Andler and Sullivan 1980; Ferree 1987; Gelb 1987; Pittman, Burt, and Gornick 1984; Simon 1982), and ideal-type depictions claim that true feminist organizations have no ties to the state. Despite such claims, most feminist organizations are linked to the state, at least minimally, and these linkages should be analyzed (see, e.g., Matthews 1989; Rodriguez 1988). 
Research on state ties can focus on whether or not a feminist organization is legally incorporated. If not, it may be (a) illegal or underground; (b) voluntary and informal (e.g., a consciousness-raising group); or (c) voluntary and formal (a local NOW chapter with structure, rules, elected officers). When an organization has a bank account or tax-free permit from the Internal Revenue Service, this provides a clue to legal-corporate status. Legally incorporated feminist organizations may be (a) not-for-profit or (b) for-profit. For-profit organizations may offer services (e.g., health care, entertainment, food, and so on), goods (books, records, clothing), or both. Does this matter? Does it correlate with other organizational features or effects? The use of profits and how this is explained to insiders and outsiders should be explored. I recently received a mail advertisement for gifts with feminist slogans and symbols informing me that profits from sales will support rape crisis centers. Is this unusual? Do other for-profit feminist organizations use their profits for women's movement ends? Is this a marketing strategy employed by nonfeminist organizations to increase sales?

Feminist organizations that are not-for-profit can be (a) mass membership organizations (e.g., NOW); (b) funded social movement (or advocacy) organizations (e.g., NARAL, WEAL; see McCarthy and Zald 1977); or (c) service organizations (rape crisis centers, health clinics, a feminist legal aid clinic, a battered women's shelter, and so on; see Riger 1984). Their ties with the state need to be studied as well.

B. Autonomy concerns whether a feminist organization is free-standing or affiliated with another organization. Ideal-type depictions describe feminist organizations as autonomous, yet my research in Florida found that only 2 of 25 rape crisis centers were free-standing (Byington et al. forthcoming; Martin et al. 1984). The majority were affiliated with battered women's shelters or community mental health agencies. Association with other organizations varied from location in a common building to complete dependence on the parent agency for personnel, funds, office space, and supplies. These data are consistent with findings of a recent study of 50 rape crisis centers nationwide (Gornick, Burt, and Pittman 1985; Harvey 1985).

The consequences of autonomy versus dependence for feminist organizations need to be studied. Some research indicates that complete autonomy is accompanied by unreliable funding and excessive demands on members' time and energy (Ferree 1987; Gornick, Burt, and Pittman 1985; O'Sullivan 1977; Simon 1982), but dependence also brings problems. Does a rape crisis center that is part of a mainstream organization water down its feminist ideology, values, and goals? Different forms and degrees of dependence have different consequences. What are the consequences of location in the same 
building; acceptance of donated space, telephone, or furniture; total financial dependence on a parent organization? Are dependent organizations compromised and thus unable to produce feminist outcomes or accomplish feminist goals? These concerns have been widely debated in the literature, but there is little comparative research on these questions.

C. Funding concerns the means by which an organization pays for itself. Most organizations occupy physical quarters, pay utility bills, purchase materials and supplies. If staff are employed, salaries and fringe benefits must be paid. If members require food, shelter, transportation, or clothing, it must be bought or donated. Funding concerns the sources from which an organization accepts financing for its operation and the strings, if any, that are attached. Funds can consist of government grants, charitable contributions, membership dues, grants and contracts from private sources, and so on. Feminist collectives in Western Europe are reluctant to accept state funds from fears of cooptation and do so only if they feel their autonomy is uncompromised (Ferree 1987; Gelb 1987). Acceptance of government funds - or charitable contributions or grants - often entails bureaucratic structures or practices (Ahrens 1980; Morrison 1982; Rothschild-Whitt 1979b; Tierney 1982); but many United States feminist organizations organizations are as likely to view themselves as coopting government as to believe that government coopts them (Harvey 1985; Mueller 1987; Pittman, Burt, and Gornick 1984; Thurston 1987).

D. Network linkages concern the content, form, intensity, and effects of feminist organizations' external ties. With which individuals, groups, and organizations do they link and why and how? Battered women's shelters and rape crisis centers in the United States interact mostly with local welfare departments, employment agencies, schools, hospitals, law enforcement organizations, and prosecutors (Martin et al. 1984). These linkages vary in frequency and intensity and reflect a range of goals, contents, and forms including, for example, confrontation, lobbying, training of staff, holding joint policy meetings, cooperating on problems or clients, sharing of resources, referring clients, and forming coalitions (Gornick, Burt, and Pittman 1985; Maxwell 1987; Morrison 1982; Schechter 1982; Thurston 1987; Tierney 1982). Analysis of the network linkages of national as well as local feminist organizations would reveal much about balances of power, exchange and dependence patterns, and interorganizational relations. Do feminist organizations interact primarily with other feminist organizations or primarily with nonfeminist organizations? Research on network ties can help feminist scholars understand the role of feminist organizations in the women's movement and their potential for fostering societal change. It can also 
add to the literature on social movements, since feminist organizations appear to be more varied, tenacious, and effective than those that have emerged in many other movements (Staggenborg 1988, 1989).

\section{CONCLUSION}

In this article, I have proceeded inductively rather than deductively. I did not begin with an ideal type of feminist organization and identify qualities that a feminist organization must have. Rather, I identified assertions about feminist organizations as ideal types and compared them with research findings on concrete feminist organizations. From this research, I identified 10 salient dimensions for analyzing feminist organizations. These dimensions can be used to compare feminist organizations with each other and with nonfeminist organizations, both in other social movements and in the mainstream. Comparative research can show us the variety of forms that feminist organizations take, help us see how they differ from and resemble one another and nonfeminist organizations, and help us identify their effects on both members and society.

The critical study of feminist organizations presents an exciting challenge to scholars of the women's movement and of organizations. If feminist scholars want control over, and a say in, what feminists have created organizationally, they must claim the topic for themselves. Those who accept this challenge can break new ground and increase understanding of feminism, organizations, and social movements.

\section{REFERENCES}

Acker, Joan. 1990. Hierarchies, jobs, and bodies: A theory of gendered organizations. Gender \& Society $4: 139-158$.

Ahrens, L. 1980. Battered women's refuges: Feminist cooperatives vs. social service institutions. Radical America 14:9-15.

Amir, D., and M. Amir. 1979. Rape crisis centers: An arena for ideological conflicts. Victimology 4:247-57.

Andler, J., and G. S. Sullivan. 1980. The price of government funding. Aegis: Magazine on Ending Violence Against Women (Winter/Spring):10-15.

Baker, Andrea J. 1982. The problems of authority in radical movement groups: A case study of lesbian-feminist organization. Journal of Applied Behavioral Science 18:323-41.

Blum, Diane B. 1982. Catfish alliance: The case of an alternative social movement organization. Ph. D. diss., Florida State University, Tallahassee.

Byington, Diane, Patricia Yancey Martin, Diana DiNitto, and M. Sharon Maxwell. Forthcoming. Organizational affiliations of rape crisis centers. Administration in Social Work. 
Cafferata, Gail L. 1982. The building of democratic organizations: An embryological metaphor. Administrative Science Quarterly 27:280-303.

Cameron, Kim. 1986. A study of organizational effectiveness and its predictors. Management Science 32:86-112.

Costain, Anne N., and W. Douglas Costain. 1987. Strategy and tactics of the women's movement in the United States: The role of political parties. In The women's movements of the United States and Western Europe, edited by M. F. Katzenstein and C. M. Mueller. Philadelphia: Temple University Press.

Costin, L. B. 1983. Women and physicians: The 1930 White House Conference on children. Social Work 28:108-14.

Delacoste, F., and F. Newman, eds. 1981. Fight back: Feminist resistance to male violence. Minneapolis, MN: Cleis.

Drachman, Virginia G. 1984. Hospital with a heart. Ithaca, NY: Cornell University Press.

Eisenstein, Zillah. 1981. The radical future of liberal feminism. New York: Longman.

Ferguson, Kathy. 1984. The feminist case against bureaucracy. Philadelphia: Temple University Press.

- 1987. Women, feminism, and collectives. Paper presented at the Annual Meeting, American Sociological Association, Chicago.

Ferraro, Kathleen J. 1981. Processing battered women. Journal of Family Issues 2:415-38.

1983. Negotiating trouble in a battered women's shelter. Urban Life 12:287-306.

Ferree, Myra Marx. 1987. Equality and autonomy: Feminist politics in the United States and West Germany. In The women's movements of the United States and Western Europe, edited by M. F. Katzenstein and C. Mueller. Philadelphia: Temple University Press.

Ferree, Myra Marx, and Beth Hess. 1985. Controversy and coalition: The new feminist movement. Boston: G. K. Hall.

Ferree, Myra Marx, and Frederick D. Miller. 1985. Mobilization and meaning: Toward an integration of social psychological and resource perspectives on social movements. Sociological Inquiry 55:38-61.

Freedman, Elizabeth. 1979. Separatism as strategy: Female institution building and American feminism, 1870-1930. Feminist Studies 5:512-29.

Freeman, Jo. 1972-73. The tyranny of structurelessness. Berkeley Journal of Sociology 17: 151-64.

- 1975. The politics of women's liberation. New York: David McKay.

1979. Resource mobilization and strategy: A model for analyzing social movement organization actions. In The dynamics of social movements, edited by M. N. Zald and J. D. McCarthy. Cambridge: Winthrop.

Garfinkel, Harold. 1967. Studies in ethnomethodology. Englewood Cliffs, NJ: Prentice-Hall.

Gelb, Joyce. 1987. Social movement "success": A comparative analysis of feminism in the United States and the United Kingdom. In The women's movements of the United States and Western Europe, edited by M. F. Katzenstein and C. Mueller. Philadelphia: Temple University Press.

Gornick, Janet, Martha R. Burt, and Karen J. Pittman. 1985. Structure and activities of rape crisis centers in the early 1980s. Crime and Delinquency 31:247-68.

Gould, Meredith. 1979. When women create an organization: The ideological imperatives of feminism. In The international yearbook of organization studies, 1979, edited by David Dunkerley and Graeme Salaman. London: Routledge \& Kegan Paul.

Hacker, Sally L., and C. Elcorobairutia. 1987. Women workers in the Mondragon system of industrial cooperatives. Gender \& Society 1:358-79.

Hall, Richard H. 1986. Complex organizations. Englewood Cliffs, NJ: Prentice-Hall. 
Harvey, Mary. 1985. Exemplary rape crisis programs: A cross-site analysis and case studies. Washington, DC: National Center for the Prevention and Control of Rape.

Jaggar, Alison M. 1983. Feminist politics and human nature. Totowa, NJ: Rowman \& Allanheld. Jaggar, Alison M., and P. Rothenburg. 1984. Feminist frameworks. New York: McGraw-Hill.

Jenkins, J. Craig, and Craig M. Eckert. 1986. Channeling black insurgency: Elite patronage and professional social movement organizations in the development of the Black Movement. American Sociological Review 51:812-29.

Johnson, J. M. 1981. Program enterprise and official cooptation in the battered women's shelter movement. American Behavioral Scientist 24:827-42.

Katzenstein, Mary Fainsod. 1987. Comparing the feminist movements of the United States and Western Europe: An overview. In The women's movements of the United States and Western Europe, edited by M. Fainsod Katzenstein and C. M. Mueller. Philadelphia: Temple University Press.

King, H. E., and C. Webb. 1981. Rape crisis centers: Progress and problems. Journal of Social Issues 37:93-104.

Kleiber, Norma, and Linda Light. 1978. Caring for ourselves: An alternative structure for health care. Vancouver, Canada: University of British Columbia School of Nursing.

Klein, Ethel. 1984. Gender politics: From consciousness to mass politics. Cambridge, MA: Harvard University Press.

-1987. The diffusion of consciousness in the United States and Western Europe. In The women's movements of the United States and Western Europe, edited by M. F. Katzenstein and C. M. Mueller. Philadelphia: Temple University Press.

Knoke, David. 1989. The mobilization of members in women's associations. In Women in twentieth century politics, edited by Patricia Gurin and Louise A. Tilly. New York: Russell Sage.

Largen, Mary Ann. 1981. Grassroots centers and national task forces: A history of the anti-rape movement. Aegis (Summer):46-52.

Leidner, Robin. Forthcoming. Stretching the boundaries of liberalism: Democratic innovation in a feminist organization. Signs.

Lorber, Judith. 1985. More women physicians: Will it mean more humane health care? Social Policy 16 (Summer):50-54.

Loseke, D. R., and S. E. Cahill. 1984. The social construction of deviance: Experts on battered women. Social Problems 31:296-310.

Lowi, T. J. 1971. The politics of disorder. New York: Basic Books.

Mansbridge, Jane. 1980. Beyond adversary democracy. New York: Basic Books.

- 1982. Fears of conflict in face-to-face democracies. In Workplace democracy and social change, edited by Frank Lindenfeld and Joyce Rothschild-Whitt, 125-37. Boston: PorterSargent.

Marieskind, H. I., and Barbara Ehrenreich. 1975. Toward socialist medicine: The women's health movement. Social Policy 6 (September/October):34-42.

Martin, Patricia Yancey. 1987a. A commentary on The feminist case against bureaucracy by Kathy Ferguson. Women's Studies International Forum 10:543-48.

-1987b. Multiple constituencies and organizational performance: Action strategies for directors. Administration in Social Work 11:223-39.

Martin, Patricia Yancey, and Diana DiNitto. 1987. The rape exam: Beyond the hospital emergency room. Women \& Health 12:5-28.

Martin, Patricia Yancey, Diana DiNitto, Diane B. Norton, and M. Sharon Maxwell. 1984. Sexual assault: Services to rape victims in Florida. Department of Health and Rehabilitative Services, State of Florida, Tallahassee. 
Martin, Patricia Yancey, and Gerald G. O'Connor. 1989. The social environment. New York: Longman.

Matthews, Nancy. 1989. Surmounting a legacy: The expansion of racial diversity in a local anti-rape movement. Gender \& Society 3:518-32.

Maxwell, M. Sharon. 1987. Rape crisis centers and mainstream human service organizations: Community education and service. Ph. D. diss., Florida State University, Tallahassee.

McCarthy, John D., and Mayer Zald. 1973. The trend of social movements in the United States: Professionalization and resource mobilization. Morristown, NJ: General Learning Press.

- 1977. Resource mobilization and social movements: A partial theory." American Journal of Sociology 82:1212-41.

Morrison, M. 1982. Shelters: National organizing against domestic violence. Off Our Backs (November): 16-18.

Mueller, Carol M. 1987. Collective consciousness, identity transformation, and the rise of women in public office in the United States. In The women's movements of the United States and Western Europe, edited by M. F. Katzenstein and C. Mueller. Philadelphia: Temple University Press.

O'Sullivan, E. 1977. Interorganizational cooperation: How effective for grassroots organizations? Group \& Organization Studies 3:347-58.

Pahl, J. 1985. Refuges for battered women: Ideology and action. Feminist Review 19:25-43.

Peterson, P., and M. A. Bond. 1985. Grassroots feminist organizations: Issues for consultants. Community Psychologist 13:15-17.

Pittman, Karen J., Martha R. Burt, and Janet C. Gornick. 1984. The internal dynamics of rape crisis centers. Washington, DC: Urban Institute.

Piven, F. Fox, and R. Cloward. 1977. Poor peoples' movements: Why they succeed, why they fail. New York: Pantheon.

Pride, A. 1981. To respectability and back: A ten-year view of the anti-rape movement. In Fight back: Feminist resistance to male violence, edited by F. Delacoste and F. Newman. Minneapolis, MN: Cleis.

Riger, Stephanie. 1984. Vehicles for empowerment: The case for feminist movement organizations. Prevention in Human Services 3:99-117.

Rodriguez, Noelie Maria. 1988. Transcending bureaucracy: Feminist politics at a shelter for battered women. Gender \& Society 2:214-27.

Rose, V. M. 1977. Rape as a social problem: A by-product of the feminist movement. Social Problems 25:75-89.

Rothschild, Joyce. 1987. Do collectivist-democratic forms of organization presuppose feminism? Cooperative work structures and women's values. Paper presented at the Annual Meeting, American Sociological Association, Chicago.

Rothschild, Joyce, and Allen Whitt. 1986. Work without bosses: Conditions and dilemmas of organizational democracy in grassroots cooperatives. Cambridge: Cambridge University Press.

Rothschild-Whitt, Joyce. 1979a. The collectivist organization: An alternative to traditional bureaucratic models. American Sociological Review 44:509-27.

-1979b. Conditions for democracy: Making participatory organizations work. In Co-ops, communes, and collectives, edited by J. Case and R.C.R. Taylor. New York: Pantheon.

Ruzek, Sheryl. 1978. The women's health movement. New York: Praeger.

Schechter, Susan. 1982. Women and male violence. Boston: South End Press.

Schlesinger, B. B., and P. B. Bart. 1982. Collective work and self-identity: The effect of working in a feminist illegal abortion collective. In Workplace democracy and social change, edited by F. Lindenfeld and J. Rothschild-Whitt. Boston: Porter-Sargent. 
Searles, P., and R. J. Berger. 1987. The feminist self-defense movement: A case study. Gender \& Society 1:61-84.

Simon, B. L. 1982. In defense of institutionalization: A rape crisis center as a case study. Journal of Sociology and Social Welfare 9:485-502.

Smith, C. B., and P. M. Marcus. 1984. Structural persistence in proactive organizations: The use of sexual assault treatment agencies. Journal of Social Service Research 7:21-36.

Smith, Dorothy. 1987. The everyday world as problematic. Boston: Northeastern University Press.

Staggenborg, Suzanne. 1988. The consequences of professionalization and formalization in the pro-choice movement. American Sociological Review 53:585-606.

1989. Stability and innovation in the women's movement: A comparison of two movement organizations. Social Problems 36:75-92.

Starr, Paul. 1979. The phantom community. In Coops, communes, and collectives, edited by J. Case and R.C.R. Taylor. New York: Pantheon.

Stinchcombe, Arthur L. 1965. Social structure and organizations. In Handbook of organizations, edited by James March. Chicago: Rand McNally.

Taylor, Verta. 1983. The future of feminism in the 1980s: A social movement analysis. In Feminist frontiers: Rethinking sex, gender and society, edited by L. Richardson and V. Taylor. Reading, MA: Addison-Wesley.

Thurston, Maxine A. 1987. Feminist women's health centers: Dilemmas and contradictions of structure, strategy, and survival. Ph. D. diss., Florida State University, Tallahassee.

Tierney, K. J. 1982. The battered women movement and the creation of the wife beating problem. Social Problems 29:207-20.

Turner, Barry A. 1986. Sociological aspects of organizational symbolism. Organization Studies 7:101-15.

Zald, Mayer N., and Roberta Ash. 1966. Social movement organizations: Growth, decline, and change. Social Forces 44:327-40.

Zimmerer, Helga. 1982. Abortion in four types of settings: Issues of control, professional expertise, and self-help. Master's thesis, Florida State University, Tallahassee.

Patricia Yancey Martin studies gender and organizations. She is interested in gender inequalities and dynamics in work and voluntary association contexts and their ties to other institutional spheres (e.g., family, politics). She is writing a book on the social construction of rape victims by actors in organizations of four types (rape crisis centers, law enforcement departments, prosecutors' offices, and hospitals), titled The Ideology and Organization of Rape. 
http://www.jstor.org

\title{
LINKED CITATIONS
}

\author{
- Page 1 of 3 -
}

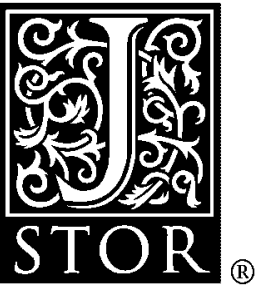

You have printed the following article:

\author{
Rethinking Feminist Organizations \\ Patricia Yancey Martin \\ Gender and Society, Vol. 4, No. 2. (Jun., 1990), pp. 182-206. \\ Stable URL: \\ http://links.jstor.org/sici?sici=0891-2432\%28199006\%294\%3A2\%3C182\%3ARFO\%3E2.0.CO\%3B2-4
}

This article references the following linked citations. If you are trying to access articles from an off-campus location, you may be required to first logon via your library web site to access JSTOR. Please visit your library's website or contact a librarian to learn about options for remote access to JSTOR.

\section{References}

The Building of Democratic Organizations: An Embryological Metaphor

Gail Lee Cafferata

Administrative Science Quarterly, Vol. 27, No. 2. (Jun., 1982), pp. 280-303.

Stable URL:

http://links.jstor.org/sici?sici=0001-8392\%28198206\%2927\%3A2\%3C280\%3ATBODOA\%3E2.0.CO\%3B2-N

\section{Separatism as Strategy: Female Institution Building and American Feminism, 1870-1930}

Estelle Freedman

Feminist Studies, Vol. 5, No. 3, Toward a New Feminism for the Eighties. (Autumn, 1979), pp.

512-529.

Stable URL:

http://links.jstor.org/sici?sici=0046-3663\%28197923\%295\%3A3\%3C512\%3ASASFIB\%3E2.0.CO\%3B2-M

Channeling Black Insurgency: Elite Patronage and Professional Social Movement Organizations in the Development of the Black Movement

J. Craig Jenkins; Craig M. Eckert

American Sociological Review, Vol. 51, No. 6. (Dec., 1986), pp. 812-829.

Stable URL:

http://links.jstor.org/sici?sici=0003-1224\%28198612\%2951\%3A6\%3C812\%3ACBIEPA\%3E2.0.CO\%3B2-8 
http://www.jstor.org

\section{LINKED CITATIONS}

- Page 2 of 3 -

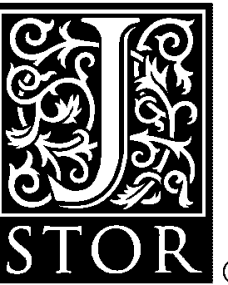

The Social Construction of Deviance: Experts on Battered Women

Donileen R. Loseke; Spencer E. Cahill

Social Problems, Vol. 31, No. 3, Thematic Issue on the Family. (Feb., 1984), pp. 296-310.

Stable URL:

http://links.jstor.org/sici?sici=0037-7791\%28198402\%2931\%3A3\%3C296\%3ATSCODE\%3E2.0.CO\%3B2-2

Resource Mobilization and Social Movements: A Partial Theory

John D. McCarthy; Mayer N. Zald

The American Journal of Sociology, Vol. 82, No. 6. (May, 1977), pp. 1212-1241.

Stable URL:

http://links.jstor.org/sici?sici=0002-9602\%28197705\%2982\%3A6\%3C1212\%3ARMASMA\%3E2.0.CO\%3B2-\%23

\section{Refuges for Battered Women: Ideology and Action}

Jan Pahl

Feminist Review, No. 19. (Spring, 1985), pp. 25-43.

Stable URL:

http://links.jstor.org/sici?sici=0141-7789\%28198521\%290\%3A19\%3C25\%3ARFBWIA\%3E2.0.CO\%3B2-8

\section{Rape as a Social Problem: A Byproduct of the Feminist Movement}

Vicki McNickle Rose

Social Problems, Vol. 25, No. 1. (Oct., 1977), pp. 75-89.

Stable URL:

http://links.jstor.org/sici?sici=0037-7791\%28197710\%2925\%3A1\%3C75\%3ARAASPA\%3E2.0.CO\%3B2-9

The Collectivist Organization: An Alternative to Rational-Bureaucratic Models

Joyce Rothschild-Whitt

American Sociological Review, Vol. 44, No. 4. (Aug., 1979), pp. 509-527.

Stable URL:

http://links.jstor.org/sici?sici=0003-1224\%28197908\%2944\%3A4\%3C509\%3ATCOAAT\%3E2.0.CO\%3B2-2

The Consequences of Professionalization and Formalization in the Pro-Choice Movement Suzanne Staggenborg

American Sociological Review, Vol. 53, No. 4. (Aug., 1988), pp. 585-605.

Stable URL:

http://links.jstor.org/sici?sici=0003-1224\%28198808\%2953\%3A4\%3C585\%3ATCOPAF\%3E2.0.CO\%3B2-G 
http://www.jstor.org

\section{LINKED CITATIONS \\ - Page 3 of 3 -}

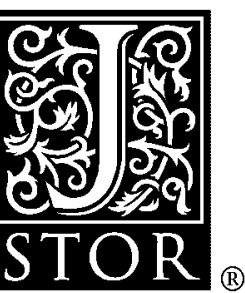

Stability and Innovation in the Women's Movement: A Comparison of Two Movement Organizations

Suzanne Staggenborg

Social Problems, Vol. 36, No. 1. (Feb., 1989), pp. 75-92.

Stable URL:

http://links.jstor.org/sici?sici=0037-7791\%28198902\%2936\%3A1\%3C75\%3ASAIITW\%3E2.0.CO\%3B2-Q

The Battered Women Movement and the Creation of the Wife Beating Problem

Kathleen J. Tierney

Social Problems, Vol. 29, No. 3. (Feb., 1982), pp. 207-220.

Stable URL:

http://links.jstor.org/sici?sici=0037-7791\%28198202\%2929\%3A3\%3C207\%3ATBWMAT\%3E2.0.CO\%3B2-O

\section{Social Movement Organizations: Growth, Decay and Change}

Mayer N. Zald; Roberta Ash

Social Forces, Vol. 44, No. 3. (Mar., 1966), pp. 327-341.

Stable URL:

http://links.jstor.org/sici?sici=0037-7732\%28196603\%2944\%3A3\%3C327\%3ASMOGDA\%3E2.0.CO\%3B2-V 